\title{
Physiological, biochemical and HSP70 and HSP90 gene expression profiles of tropical abalone Haliotis squamata in response to Vibrio alginolyticus infection
}

\author{
Ngurah S. Yasa ${ }^{1,2}$, Murwantoko ${ }^{1,{ }^{*}}$, A. Isnansetyo ${ }^{1}$, Niken S. N. Handayani ${ }^{3}$, Gemi Triastutik $^{2}$, Lutfi Anshory ${ }^{2}$ \\ ${ }^{1}$ Faculty of Agriculture, Universitas Gadjah Mada, Jl. Flora, Bulaksumur, Yogyakarta, 55281, Indonesia \\ ${ }^{2}$ National Broodstock Centre for Shrimp and Mollusc, Abalone Hatchery Unit, Tigaron, Karangasem, Bali, Indonesia \\ ${ }^{3}$ Department of Genetics, Faculty of Biology, Universitas Gadjah Mada, Jl. Teknika Selatan, Sekip Utara, Bulaksumur, Yogyakarta, 55281, \\ Indonesia \\ ${ }^{*}$ Corresponding author: murwantoko@ugm.ac.id
}

SUBMITTED 9 November 2019 REVISED 10 February 2020 ACCEPTED 11 March 2020

\begin{abstract}
Vibrio spp. have been known responsible for fish diseases in marine and brackish-water systems in the tropics regions. Heat shock proteins are a highly conserved protein group that is known for its rapid response to environmental stresses, including infection. This study aimed to investigate physiological and biochemical responses of tropical abalone Haliotis squamata to Vibrio alginolyticus infection. Abalones were infected with V. alginolyticus by intramuscular injection at a dose of $10^{5}, 10^{6}, 10^{7} \mathrm{cfu} /$ abalone. The expression of HSP70 and HSP90 genes, the activity of superoxide dismutase, phenol oxidase and catalase enzymes, histology, falling and mortality were observed at 12, 24, 48, 72, and $96 \mathrm{~h}$ post-infection (hpi). The different expression of HSPs was found in this study. While the expression of HSP70 was downregulated after infection, the expression of HSP9O was upregulated at $12 \mathrm{hpi}$ and followed by downregulated after 24 hpi for $10^{6}$ cfu infection, but expressed at a normal level for $10^{5}$ infection treatment. The expression ofsuperoxide dismutase and catalase increased within $12 \mathrm{hpi}$, and the expression of phenol oxidase increased after $24 \mathrm{hpi}$. V. alginolyticus is virulent with LD $\mathrm{LD}_{50}$ of less than $10^{5} \mathrm{cfu}$ on $\mathrm{H}$. squamata with an average weight of $5.13 \mathrm{~g}$, and caused enlargement of hemolymph sinus and development intraepithelial and intramuscular abscesses.
\end{abstract}

KEYWORDS Haliotis squamata; Heat Shock Protein (HSP); histology; physiology; Vibrio alginolyticus

\section{Introduction}

The development of aquaculture on increasing intensification and commercialization of aquatic production will increase occurring major disease problems (BondadReantaso et al. 2005). Abalones or ear shells have a low shell, open spiral structure, and are characterized by several open respiratory pores in a row near the shell's outer edge. Abalone species are economically valuable for fishery production in the temperate or sub-tropical areas. Whereas, the large size of abalones are distributed in temperate seas, the small size abalones are distributed at widerange geographical distribution in warm water, including Indonesia. The commercial aquaculture of the small size of abalone has already well developed, especially in East Asia (Hsu and Gwo 2017). The aquaculture industry has been overwhelmed with its share of diseases and problems caused by several pathogens (Bondad-Reantaso et al. 2005). In Taiwan, the production of small abalone has been dramatically decreased in the past 15 years due to the lack of suitable diatom feed for larvae, poor water quality, habitat degradation, genetic problems, disease and infection problems (Hsu and Gwo 2017).

Given that bacteria can survive well in aquatic environments independently of their hosts, bacterial diseases have become major impediments to aquaculture, especially when the water temperature is warm (Pridgeon and Klesius 2012). The most frequently encountered bacterial agents associated with fish diseases in marine and brackish-water systems in the tropical environments are Vibrio spp. (Karunasagar et al. 2003). Vibrio harveyi is known to be pathogenic in a large range of vertebrates and invertebrates, including molluscs. Abalone diseases due to the pathogen $V$. harveyi have been described in Haliotis diversicolor, $H$. laevigata and $H$. tuberculata causing septicaemia. The evidence of vibriosis on abalone has outbroken in Taiwan in 2000 which was caused by $V$. parahaemolyticus and made a significant economic loss in abalone ( $H$. diversicolor supertexta $\mathrm{L}$.) industry (Cheng et al. 2004; Cai et al. 2006b). The V. alginolyticus H11 strain has been isolated from a mass mortality out- 
breaks of small abalone $H$. diversicolor supertexta with abscess/ulcers in the mantle that occurred in 1998 at KaoHsiung, Taiwan. This strain and its extracellular products were virulent to small abalones with $\mathrm{LD}_{50}$ values of $3.6 \times$ $10^{5}$ colony forming units (cfu) and $2.96 \mu \mathrm{g}$ protein/g body weight, respectively (Liu et al. 2001). Vibrio alginolyticus also caused disease on post larvae and small juvenille $H$. diversicolor. This bacterium is virulent with $\mathrm{LD}_{50}$ as 1.0 $\times 10^{4} \mathrm{cfu} / \mathrm{ml}$ on post larvae (Cai et al. 2006a).

Animals have defense mechanisms against the pathogen, which is composed of innate and adaptive immune systems. The innate immune system is the only defense system that existed in invertebrates. This innate immune system is the first line defense against non-self pathogens and can be divided into physical barriers, cellular, and humoral components. Specifically, humoral parameters include growth inhibitors, various lytic enzymes and components of the complement pathways, agglutinins, precipitins, natural antibodies, cytokines, chemokines, and antibacterial peptides. Furthermore, several external and internal factors can also influence the activity of innate immune parameters. The cellular immune system is performed by several types of cells (Magnadóttir 2006).

Hemocytes in molluscs are consisted of agranular and granular hemocytes, which are involved in phagocytosis, an important process of eliminating microorganisms or foreign particles. During phagocytosis, several types of reactive oxygen intermediates (ROIs) are produced, such as: superoxide anion $\left(\mathrm{O}_{2}\right)$, hydrogen peroxide $\left(\mathrm{H}_{2} \mathrm{O}_{2}\right)$, singlet oxygen, and hydroxyl radical. The release of superoxide anion is known as the respiratory burst, and it plays an essential role in antibacterial activity (Cheng et al. 2004). Acid phosphatase (ACP) and alkaline phosphatase (AKP) are important for innate immune defense in the small size of abalones. Superoxide dismutase (SOD) is a key antioxidant enzyme playing a first-line protective role against reactive oxygen species (ROS) by converting superoxide $\left(\mathrm{O}_{2-}\right)$ into $\mathrm{H}_{2} \mathrm{O}_{2}$. The AKP, and SOD activities of diseased abalones were significantly lower than in the healthy group (Di et al. 2016). Several enzymes on abalone have been evaluated in response to pathogen infection on $H$. diversicolor (Yao et al. 2019), and on greenlip abalone (H. laevigata) in the high water stress (Buss et al. 2017).

Heat shock proteins (HSPs) are a group of highly conserved chaperone proteins expressed by the cell that respond to unfavorable environmental changes (Fang et al. 2019). The HSPs are considered as ubiquitous protein and widely preserved in prokaryotic and eukaryotic organisms (Roberts et al. 2010). These proteins have functioned as cellular defenses, prevent protein denaturation, and assist in the reintroduction and removal of denatured protein due to biotic and abiotic pressures (Wang et al. 2004). In aquatic organisms, expression of HSP genes was increased as a response to several stresses, such as heat (Park et al. 2015), organic pollutants (Paulino et al. 2014), correlations between metals (Qian et al. 2012), and Vibrio infections (Rungrassamee et al. 2010).
Many studies on physiology and disease have been conducted on abalones from the temperate or subtropical zone (Rungrassamee et al. 2010; Di et al. 2016; Fang et al. 2019; Yao et al. 2019). However, only limited studies have been addressed on tropical abalone. The $H$. squamata is an indigenous species with an excellent taste and has been caught on the southern coast of Bali. This species was started to be cultured, especially in Bali. In this study, we investigated the biological responses of tropical abalone $H$. squamata in the response to $V$. alginolyticus infection. This study is the first investigation of $V$. alginolyticus infection in $H$. squamata in Indonesia with a comprehensive evaluation of mortality, histology, enzymes activity, and HSP gene expression.

\section{Materials and Methods}

\subsection{Animal collection and maintenance}

The uniform and high quality abalone seeds are very essential for this study, then this research begins with the hatching of abalone in the Abalone Hatchery Unit, National Broodstock Center for Shrimps and Mollusc in Tigaron, Karangasem, Bali, Indonesia. The abalones with a normal morphological and appearance, agile movements, sticking firmly to the substrate, minimal size of the shell length 4 $\mathrm{cm}$ were selected as broodstocks for use in this study. The broodstocks were maintained in fiberglass tubs with PVC pipes as shelters and fed with Gracillaria sp. and Ulva sp. seaweed at the dosage of $10-20 \%$ of biomass/day.

The stress treatment was applied to mature gonad abalones for inducing the spawning. The stress was addressed by lifting the basket of the broodstock from the water tank for one hour then put it back into the water. Then the broodstock was maintained in a tank with a flowing water system until spawning. Eggs produced from spawning abalone were harvested using an egg collector. After 12 to $13 \mathrm{~h}$ of incubation, the eggs hatched into first-stage swimming larvae, trochophores. The trochopores within a few hours become a veliger larvae. The veliger larvae were fed with attached diatoms (Nitzschia sp. and Navicula sp.) which attached on the substrate rearing plate.

After one month rearing, the veliger larvae reached a juvenile stage at size diameter of shell more of than $0.6 \mathrm{~cm}$. The juveniles were reared on the basket in the tank and fed with macroalgae Gracillaria sp. and Ulva sp. The grading was carried out every two months for continue rearing on relatively same size. After eight months of rearing, the juvenile abalone $H$. squamata with an average shell length of $32.97 \pm 1.83 \mathrm{~mm}$ and an average weight of $5.13 \pm 0.83$ g were used for this study. The abalones from the hatchery were acclimatized to laboratory conditions for one week. During acclimatization, abalones were reared on pipe basket in the tank with seawater at a salinity of $34 \mathrm{~g} / \mathrm{L}$, the temperature at $29-30{ }^{\circ} \mathrm{C}$ and fed with seaweed Gracillaria sp. twice a day. 


\subsection{Vibrio alginolyticus infection}

A pathogenic strain of $V$. alginolyticus was received from Fish Disease and Environmental Inspection Center at Serang, Banten, Indonesia. The bacterium was cultured on nutrient broth and incubated at $35{ }^{\circ} \mathrm{C}$ for $48 \mathrm{~h}$. The bacterium was harvested, washed and suspended PBS on at desired concentration for infection treatments.

The $V$. alginolyticus infection was conducted by intramuscular injection on pallial sinus using 25 gauge $1 \mathrm{~mL}$ syringe at a concentration of $10^{5}, 10^{6}, 10^{7} \mathrm{cfu} /$ abalone with a volume of $100 \mu \mathrm{L}$. For the control, abalones were injected with $100 \mu \mathrm{l}$ of PBS. After injection, the abalones were kept on pipe baskets and observed on the superoxide dismutase (SOD), phenol oxidase (PO) and catalase (CAT) enzyme activity, Heat shock proteins (HSPs) expression, survival rate, falling rate, and histology.

\subsection{SOD, PO, and CAT enzyme activity}

The evaluation of enzyme activity was performed by sampling at $0,12,24,48,72$, and 96 h post $V$. alginolyticus infection. The hemolymph was collected and pooled from three animals for measuring the SOD, PO, and CAT activities. The SOD activity was determined by measuring the ability to inhibit the reduction of photochemical nitroblue tetrazolium chloride (NBT), as described previously (Datkhile et al. 2009) with SOD Kit-WST (water-soluble tetrazolium salt) Access (Dojindo, Japan). Briefly, $40 \mu \mathrm{L}$ of hemolymph was added into $360 \mu \mathrm{L}$ buffer phosphate, then centrifuged at $6000 \mathrm{~g}$ at $4{ }^{\circ} \mathrm{C}$ for $7 \mathrm{~min}$. The supernatant was then heated up at $65^{\circ} \mathrm{C}$ for 5 min to obtain the crude extract. Finally, $150 \mu \mathrm{L}$ of the crude extract was added with $50 \mu \mathrm{L}$ of nitroblue tetrazolium (NBT) reagent (0.1 Mm EDTA, $13 \mu \mathrm{M}$ methionine, $0.75 \mathrm{mM}$ NBT and 20 $\mu \mathrm{M}$ riboflavin in $50 \mathrm{mM}$ phosphate buffer, $\mathrm{pH} 7.8$ ) and incubated for $2 \mathrm{~min}$. Then the optical density was measured at $450 \mathrm{~nm}$ using a spectrophotometer.

Phenol oxidase activity was measured spectrophotometrically by recording the formation of dopachrome produced from L-dihydroxyphenylalanine (L-DOPA) according to (Hooper et al. 2014). One hundred microliters of hemolymph plasma were transferred in duplicate to 96well microplate wells. The $100 \mu \mathrm{l}$ of L-DOPA (30 mM L3,4-dihydrophenylalanine, Sigma D9628, in $\mathrm{HCl} 0.2 \mathrm{M}$, $\mathrm{pH}$ 8) was added to each well and mixed for $10 \mathrm{~s}$. The absorbance at $492 \mathrm{~nm}$ was recorded every $5 \mathrm{~min}$ at $20^{\circ} \mathrm{C}$ for over than $30 \mathrm{~min}$, using a microplate reader Heales ${ }^{\circledR}$ MB-580, (Shenzhen Huisong Technology China).

Catalase activity was measured colorimetrically by CAT activity Assay Kit (GeneWay, Biotech) according to the manufacture instruction. The level of $\mathrm{H}_{2} \mathrm{O}_{2}$ loss was measured by reading absorbance with a microplate reader at $492 \mathrm{~nm}$. One unit of enzyme was defined as the amount of enzyme required to convert $1 \mathrm{~mol}$ of $\mathrm{H}_{2} \mathrm{O}_{2}$ to the product in one min in $\mathrm{pH} 4.5$ at $25^{\circ} \mathrm{C}$.

\subsection{HSPs expression}

The hemolymph was collected from the animal using a syringe at $0,12,24,48,72$, and 96 h post $V$. alginolyticus infection. The hemolymphs from three animals were pooled in microtube then immediately proceed for RNA extraction or kept at $-80{ }^{\circ} \mathrm{C}$ until ready to be used. Total RNA was extracted from hemolymph using QuickRNA MiniPrepPlus Kit (R1058) (Zymo Research) following manufacturer protocol. The integrity of RNA was assessed by electrophoresis on $1.2 \%$ agarose gel. The purity of RNA was verified by measuring absorbance at 260 nm and $280 \mathrm{~nm}$ with NDD 2000 (Nano Drop Technologies, USA). The cDNA was synthesized by mixing the $100 \mu \mathrm{g}$ of RNA with others component of ReverTra Ace ${ }^{\circledR}$ qPCR RT Master Mix (Toyobo, Japan). The mixture was incubated at $37^{\circ} \mathrm{C}$ for $15 \mathrm{~min}$ and at $50{ }^{\circ} \mathrm{C}$ for $5 \mathrm{~min}$, then followed by incubation at $98^{\circ} \mathrm{C}$ for $5 \mathrm{~min}$ for enzyme inactivation.

HSP gene expression was measured by real-time PCR using Thunderbird SYBR ${ }^{\circledR}$ qPCR kit with Applied Biosystem machine (ABI, USA). The $2 \mu \mathrm{L}$ cDNA was used in each reaction and analyzed in triplicate. The HSP90 F (CCAGGAAGAATATGCCGAGT) and HSP90 R (CACGGAACTCCAACTGACC) primers were used to evaluate $H S P 90$ expression, while HSP70 F (CCGCTCTAGAACTAGTGGAT) and HSP70 R (CCGCCAAGTGGGTGTCT) primers were used to evaluate HSP90 expression, and $\beta$-actin F (GGGTGTGATGGTCGGTAT) and $\beta$-actin F (AGCGAGGGCAGTGATTTC) primer pairs were used to determining the expression of $\beta$-actin as an internal control (Farcy et al. 2007). The thermal cycling condition was $95{ }^{\circ} \mathrm{C}$ for 30 $\mathrm{s}$ for the initial denaturation stage, followed by 40 cycles of $95{ }^{\circ} \mathrm{C}$ for $5 \mathrm{~s}, 58{ }^{\circ} \mathrm{C}$ for $30 \mathrm{~s}$, and $72{ }^{\circ} \mathrm{C}$ for $30 \mathrm{~s}$ for final extension stage. At the end of reaction, the melting or dissociation curve analysis to ensure reaction specificity. This analysis was applied by increasing temperature from $65{ }^{\circ} \mathrm{C}$ to $95^{\circ} \mathrm{C}$, with rate increasing the temperature at 0.5 ${ }^{\circ} \mathrm{C}$ sec-1.

\subsection{Falling rate}

The abalones were injected intramuscularly with $V$. alginolyticus at a dose of $10^{5}, 10^{6}, 10^{7} \mathrm{cfu} /$ abalone. Falling rate was conducted to evaluate the changes of adhesion ability of abalones on the PVC substrate. Thirty abalones were attached to vertical PVC pipe substrates in the aquarium. The numbers of fallen abalones from the vertical substrate was recorded every $12 \mathrm{~h}$. This experiment was conducted in triplicate.

\subsection{Survival rate}

Thirty abalones from each dose infection treatment were transferred to aquaria. The mortality of abalone was recorded daily. The death of abalone was indicated by fallen from the wall, laid at the bottom with upside-down position or the shell at the floor. This experiment was conducted in triplicate. 


\subsection{Histological analysis}

Histology was conducted to observe the effects of $V$. alginolyticus infection on the foot muscle structure. The abalones were collected at $96 \mathrm{hpi}$, the shells were removed, and the tissues were fixed in Bouin's solution. The tissues were proceeded on standard histology, then sectioned at a thickness of $5 \mu \mathrm{m}$ and stained with H\&E. The slides were observed under light microscopy (ZEISS Primovert P35C). The level of histological alterations in the foot was determined descriptively.

\section{Results and Discussion}

\subsection{HSP70 and HSP90 gene expression of $H$. squa- mata}

Heat shock proteins (HSPs) are a group of highly conserved proteins which responsible for responding to disease infection. The expression profile of the two HSP genes in the abalone hemolymph after $V$. alginolyticus infection was shown in Figure 1. HSP70 and HSP90 were expressed in a different pattern. The expression level of HSP70 was decreased rapidly in the first $12 \mathrm{~h}$ after infection (hpi), and remained in a low expression level until at the end of the experiment at 96 hpi (Figure 1). In contrast, the expression of HSP90 gene was increased in all infection treatments at $12 \mathrm{hpi}$, with the $H S P 90$ expression at $10^{7}$
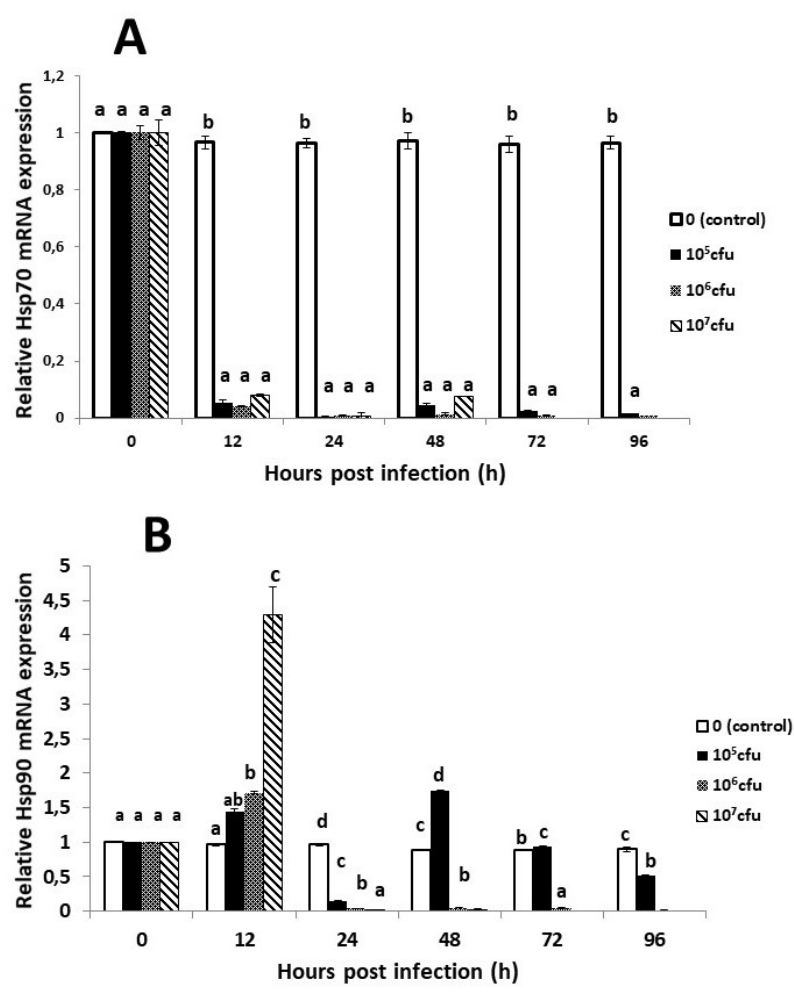

FIGURE 1 The relative expression levels HSP70 (A) and HSP90 (B) of abalone $H$. squamata at various $V$. alginolyticus infection as indicated. Different lowercase letters on each observation indicates a significant difference of the expression $(P<0.05)$ compared with the control using Tukey's test. cfu infection treatment reached 4.5 times over the control. Next, the HSP90 expression was decreased in all infection treatment after $24 \mathrm{hpi}$. Moroever, the HSP90 expression at $10^{6}$ and $10^{7} \mathrm{cfu}$ infection treatments were still in a low level until 96 hpi. Meanwhile, the HSP90 at $10^{5}$ cfu infection treatment was expressed at the nearly same level with control (Figure 1B).

\subsection{Biochemical responses of $H$. squamata to V. algi- nolyticus infection}

Hemocytes are involved in phagocytosis for the elimination of microorganisms or foreign particles. Several enzymes play important roles in phagocytosis process. Therefore, the superoxide dismutase (SOD), phenol oxidase (PO) and catalase (CAT) enzyme activity were measured to determine abalone responses to $V$. alginolyticus infection at 0, 12, 24, 48, 72, and 96 hpi (Figure 2). Result showed that the SOD activity was increased in abalone infected with $V$. alginolyticus $(P<0.05)$ compared to the control after $12 \mathrm{~h}$ with the highest increased of SOD activity was observed in abalones with $10^{6}$ cfu infection. Moreover, after $24 \mathrm{~h}$, SOD activity was decreased significantly in the abalone with $10^{5}$ and $10^{5}$ cfu infection treatments
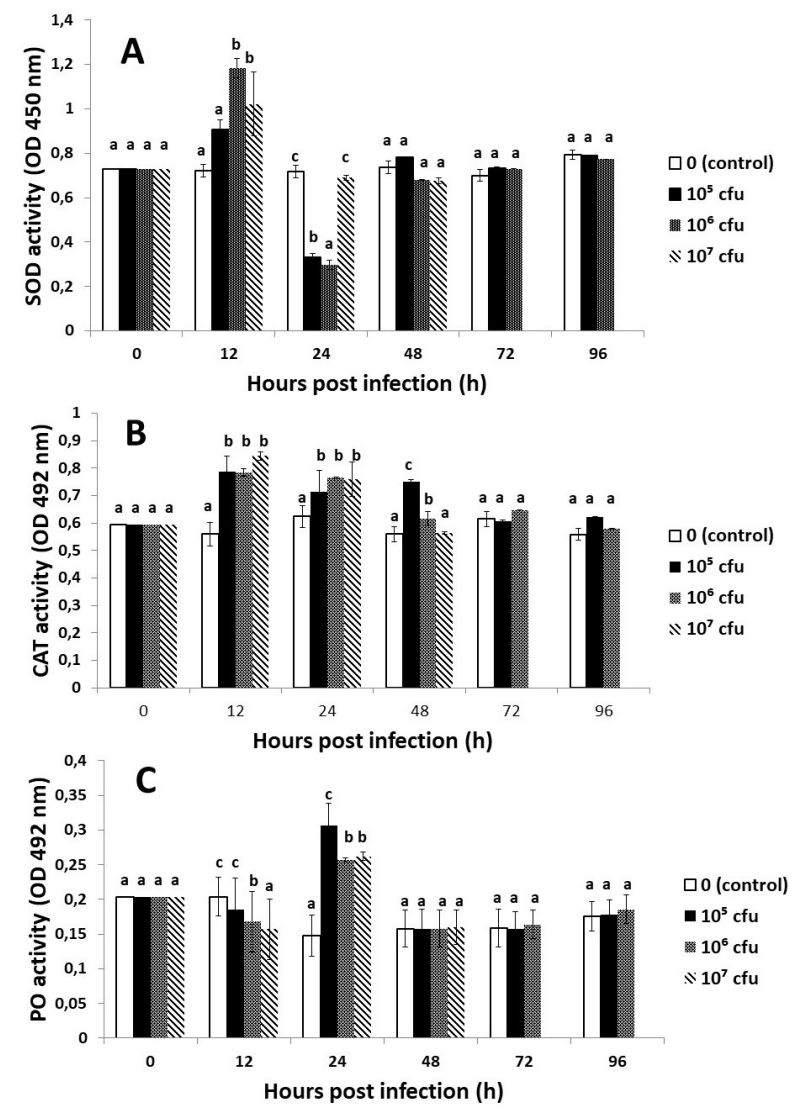

FIGURE 2 Antioxidant enzyme activity of superoxide dismutase (A) catalase (B) and phenol oxidase (B) and of abalone $H$. squamata at various V. alginolyticus infection as indicated. Different lowercase letters on each observation indicates a significant difference of the enzyme activity $(P<0.05)$ compared with the control using Tukey's test. 


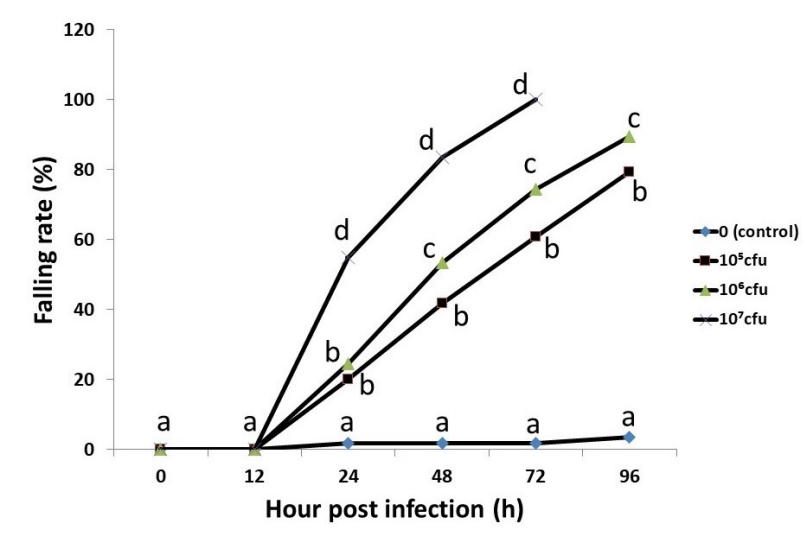

FIGURE 3 Falling rate (\%) at different observation of abalones $\mathrm{H}$. squamata on various V. alginolyticus infection as indicated. Different lowercase letters on each observation indicates a significant difference of the falling rate $(P<0.05)$ compared with the control using Tukey's test

compared to thethe control. At 96 hpi, the SOD activity of all infection treatments was the same level with control (Figure 2A). The CAT enzyme activities significantly increased in all of the infection treatments from $12 \mathrm{hpi}$ until 48 hpi $(P<0.05)$. Then CAT activity tended to decrease and reached the normal condition at 72 hpi (Figure 2B). The PO activity of infection treatments was significantly decreased at 12 hpi $(P<0.05)$ compared to the control in $24 \mathrm{~h}$. After $24 \mathrm{~h}$, the PO activity tended to decreased and reached same level of expresssion with control at $48 \mathrm{hpi}$ (Figure 2C).

\subsection{Physiologyical responses of $H$. squamata to V. al- ginolyticus infection}

The adhesion of abalones to the substrate was an important end-point of their health and protection from environmental threats. The falling rate of the substrate was observed in $H$. squamata after it was exposed to various level of bacterial densities (Figure 3). On the other hand, there was no statistically significant difference of the falling rate abalones $H$. squamata's substrate in the control group. However, abalones at the concentration of $10^{5} \mathrm{cfu}, 10^{6} \mathrm{cfu}$, and $10^{7} \mathrm{cfu}$ treatments at $48 \mathrm{hpi}$ showed falling rates as $50 \%, 70 \%$, and $100 \%$ respectively. Furthermore, after 72 $\mathrm{h}$, the falling rates were $80 \%$ at the concentration of $10^{5}$ cfu and $90 \%$ for $10^{6}$ cfu treatments.

In this infection experiment of $V$. alginolyticus, at the concentration ranging from $10^{5}$ to $10^{7} \mathrm{cfu}$, the mortality was started at 24 hpi in all infected treatments. The survival rate of $10^{7}$ cfu infection treatment was decreased significantly and all of the abalones were deceased by $72 \mathrm{hpi}$. Moroever, at the concentration of $10^{5}$ and $10^{6}$ cfu infection treatments, $21.6 \%$ and $11.6 \%$ of animals still alive at 96 hpi. As shown in Figure 4, in the control group the mortality of abalones was not observed and a $96.6 \%$ of survival rate was achieved until 96 hpi. Taken together, all those data suggested that $\mathrm{LD}_{50}$ of this $V$. alginolyticus in $H$. squamata with an average weight of $5.13 \mathrm{~g}$ was less

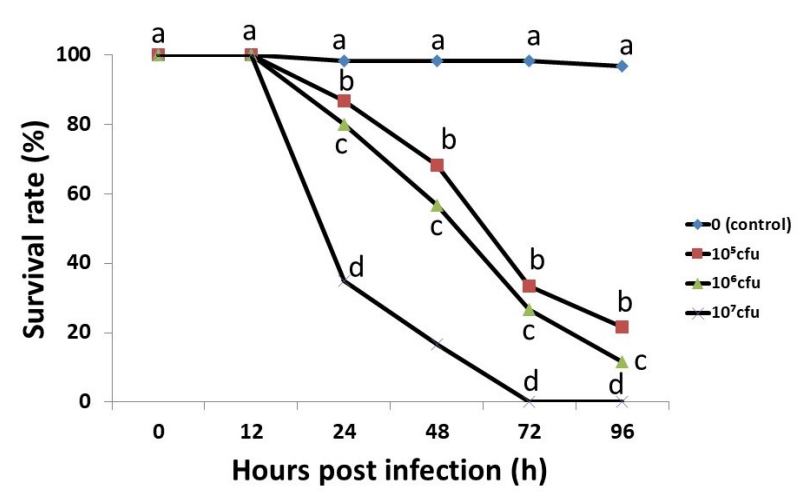

FIGURE 4 Survival rate (\%) at different observation of abalones $H$. squamata on various V. alginolyticus infection as indicated. Different lowercase letters on each observation indicates a significant difference of the survival rate $(P<0.05)$ compared with the control using Tukey's test.

than $10^{5} \mathrm{cfu}$. This result indicated that V. alginoliyticus is a virulent bacterium against abalone $H$. squamata. Liu et al. (2000) reported that $\mathrm{LD}_{50}$ of $V$. parahaemolyticus on abalone $H$. diversicolor supertexta weighing $10-14 \mathrm{~g}$ is 1.6 $\times 10^{5} \mathrm{cfu}$, and mortalities occurred within $2 \mathrm{~d}$ of infection. While Liu et al. (2001) reported that $\mathrm{LD}_{50}$ of V. alginolyticus strain $\mathrm{H}-11$ on abalone $H$. diversicolor supertexta is $3.6 \times 10^{5} \mathrm{cfu}$. Therefore, the result of this study is in a good agreement with the previous report.

\subsection{Histology changes of $\mathrm{H}$. squamata in response to V. alginolyticus infection}

The abalone attaches and moves using its foot muscles along to the substrate for feeding and other activities. Due to its vital role, the effect of $V$. alginolyticus infection on the foot muscle was investigated and the histology analysis was conducted in this study. The normal foot of $H$. squamata consisted of an epithelial layer (EL), connective tissue layer, and muscle layer (ML) in a crosssection view (Figure 5A). The epithelial layer included mucous cells, eosinophilic granule cells (Egc), and melano granule cells (Mgc) (Figure 5A). The muscle layer was broad and consisted of muscle fiber bundles (Mfb) and hemolymph sinus (Hs) (Figure 5A). Muscle fiber bundles distributed evenly to fulfilled the muscle layer as longitudinal fibers.

In the $1 \times 10^{5} \mathrm{cfu}$ infection treatment, the structural was changed in the abalone foot included small abscess (Abs) in the muscle layer, vacuolation, and enlargement of hemolymph sinus (Hs) in the muscle layer (Figure $5 \mathrm{~B}$ ). Whereas in the $1 \times 10^{6}$ cfu infection treatment, many abscesses (Abs) both in the intra epithelial layer and muscle layer, and enlargement of hemolymph sinus (Hs) in the muscle layer were observed (Figure 5C). In addition, in the $1 \times 10^{7} \mathrm{cfu}$ infection treatment, the structural changes in the abalone foot included intrusion of hemolymph through the hemolymph sinus and moving closed to the epithelial layer post the enlargement of hemolymph sinus (Hs) and decreasing the density of muscle fiber bundles in the mus- 

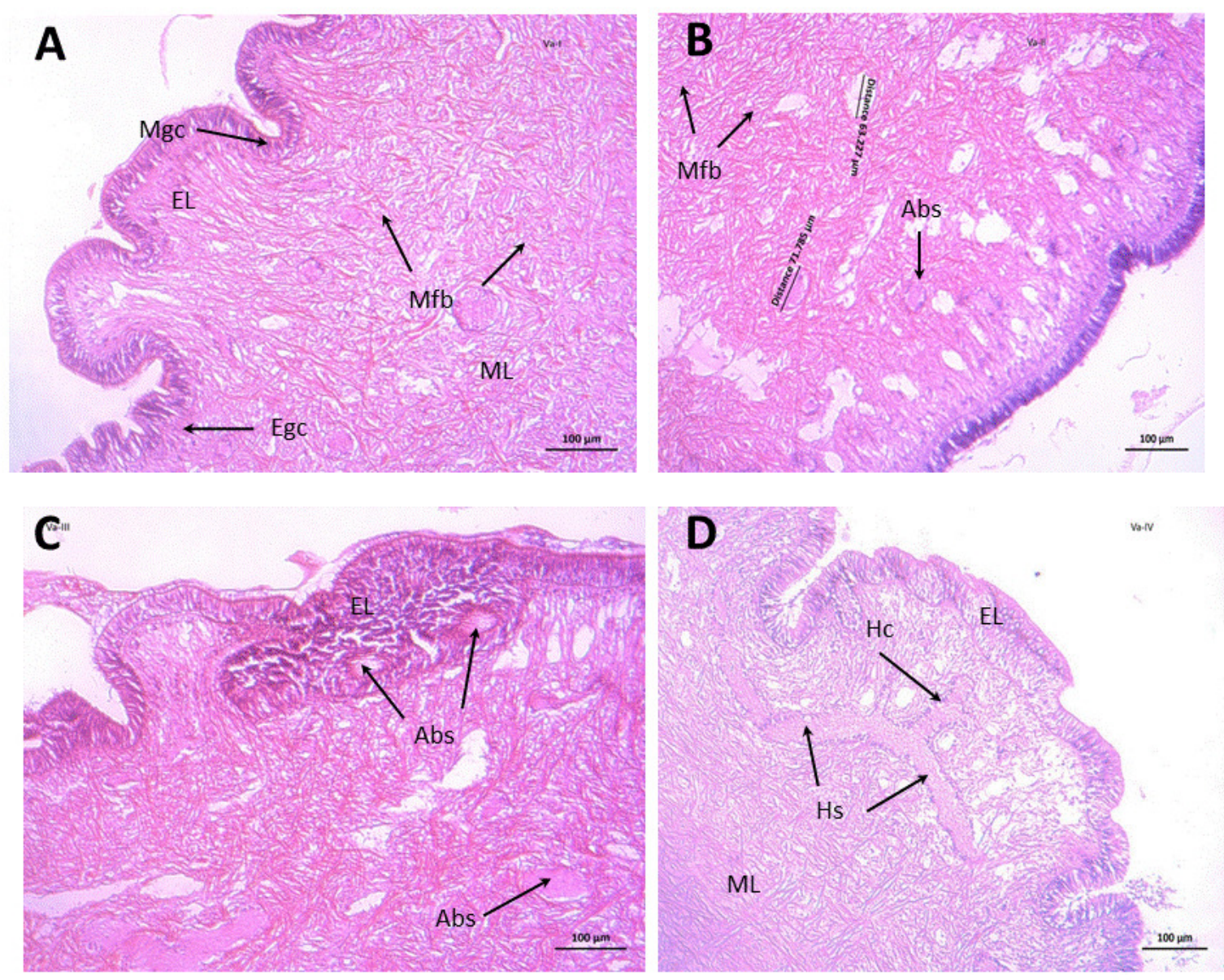

FIGURE 5 Histological section of abalone H. squamata foot (100x magnification). Control treatmen (A), infected with V. alginolyticus at concentrations of $1 \times 10^{5} \mathrm{cfu}(\mathrm{B}) 1 \times 10^{6} \mathrm{cfu}(\mathrm{C})$ and $1 \times 10^{7} \mathrm{cfu}(\mathrm{D})$. Vacuolations, enlargement of hemolymph sinuses and abscesses were found in infection treatments. $\mathrm{ML}=$ muscle layer, $\mathrm{Hs}=$ hemolymph sinus, EL=epithelial layer, $\mathrm{Abs}=$ abscesses, Egc = eosinophilic granule cell, $\mathrm{Hc}=$ haemocyte cell, $\mathrm{Mfb}=$ muscle fibre bundle, $\mathrm{Mgc}=$ melano granule cell .

cle layer (Figure 5D). Thus, the infection of V. alginolyticus induced enlargement of hemolymph sinus, development of abscess intra epithelial and intramuscular, and the intrusion of hemolymph closed to epithelial layer due to the disintegration of the epithelial layer and muscle layer of abalone foot tissues. The histological alterations of the foot in abalones were more severe with increasing bacterial concentration.

\subsection{Discussion}

Abalone species are economically valuable for fishery production in the temperate or sub-tropical areas, so that the commercial aquaculture of abalone has developed in many countries. However, this industry has faced several problems, and one of the most important problems is diseases (Hsu and Gwo 2017). Vibrio spp. bacteria have been identified as pathogenic bacteria that causes diseases in many species of abalone and it can lead to the economic significant losses (Liu et al. 2001; Cheng et al. 2004; Cai et al. 2006b). Several parameters of disease mechanism have been investigated on disease-related gene expression, enzyme activity of abalone (Rungrassamee et al. 2010; Di et al. 2016; Fang et al. 2019; Yao et al. 2019). However, the study on those subjects is very limited in Indonesia. This study is the first investigation the effect of $V$. alginolyticus infection on Indonesian abalone $H$. squamata with a comprehensive evaluation of mortality, histology, enzymes activity, and HSP gene expression.

The large size of abalones are distributed in temperate seas, while the small size abalones are distributed at widerange geographical distribution in warm water, including Indonesia. The commercial aquaculture of the small size has developed well, especially in East Asia (Hsu and Gwo 2017). The aquaculture industry has been overwhelmed with its share of diseases and problems caused by several pathogens (Bondad-Reantaso et al. 2005). In Taiwan, the production of small abalone has dramatically decreased in the past 15 years which caused by lack of suitable diatom feed for larvae, poor water quality, habitat degradation, and genetic problems, disease and infection problems (Hsu and Gwo 2017).

Heat shock protein (HSP) family forms the most ancient defense system in all living organisms, from bacteria to humans. Heat shock proteins are classified into six ma- 
jor families: small HSPs, HSP40, HSP60, HSP70, HSP90, and HSP110 according to their molecular weight. Among these HSPs, HSP70 and HSP90 are common and widely studied heat-related proteins (Wang et al. 2004; Xie et al. 2015). On abalone Haliotis diversicolor, the HSP is expressed in the mantle, mucous gland, muscle, gills, digestive tract, hemocytes, and hepatopancreas tissues. However, the expression level of HSP differed among tissues with a significantly higher expression level being in hepatopancreas, followed by hemocytes (Fang et al. 2019). In this experiment, we studied the expression HSP on abalone form hemocytes. Taking samples as hemocytes has advantages, due to its easiness to get hemocytes from animals and its low risk to abalone conditions.

In channel catfish (Ictalurus punctatus), Heat shock protein $(H S P)$ genes are differentially expressed after $E d$ wardsiella ictaluri or Flavobacterium columnare bacterial infections. The expression of those genes exhibited both temporal and spatial regulation. The induction of HSP genes was observed soon after bacterial infection, suggesting their distinct roles in immune responses and disease defenses (Xie et al. 2015). The expression level of HSP70 and HSP90 of Penaeus monodon genes have been reported significantly increased after a 3-h exposure to $V$. harveyi (Rungrassamee et al. 2010). In this study, we evaluate the expression of HSP90 and HSP70 of abalone Haliotis squamata in response to Vibrio alginolyticus infection at $12 \mathrm{hpi}$.

In this study, the expression of HSP90 was upregulated in 12 hpi in all doses infection and reached the highest upregulation more than four times at the treatment of $10^{7} \mathrm{cfu}$ infection compare to the control. The HSP90 expression was then down-regulated after $24 \mathrm{hpi}$ to one seventh to one seventeenth for infection treatments compared to the control (Figure 1). This expression pattern was similar to study of Wang et al. (2011) that transcription of HSP90 of disk abalone ( $H$. discus) gene in response to bacterial LPS challenge significantly increased within $2 \mathrm{~h}$ and reached highest transcription at $4 \mathrm{hpi}$, then recovered to the normal level of transcription in $24 \mathrm{~h}$ finally. The low expression of HSP90 on high density infection $\left(10^{7} \mathrm{cfu}\right)$ may occur due to the severe condition abalone, which leads to mortality.

Heat-inducible forms of HSP70 play a central role in stress tolerance by the promotion of growth at moderately high temperature and/or protecting organisms from death at extreme temperature (Cheng et al. 2007). HSP70 has been reported exhibits physiological and ecological importance in response to pathogen infection and environmental stress. For example, heat shock in fish was the most effective stress stimuli to induce HSP70 response compared to other stressors including hypoxia and air exposure. In mollusks, HSP70 transcripts increased significantly after acute heat stress. Up-regulation of HSP70 was observed after $V$. parahaemolyticus infection in adult bay scallops Argopecten irradians. The expression of HSP70 in the zebra mussel Dreissena polymorpha showed a time-dependent increase after lipopolysaccharide (LPS) stimulation (Fang et al. 2019).

The expression levels of HSP70 and HSP90 of Pe- naeus monodon significantly increased after a 3-h exposure to V. harveyi (Rungrassamee et al. 2010). The bacterial challenge of $V$. anguillarum on Pacific abalone $(H$. discus hannai) showed a time-dependent expression of the HSP gene with a significant increase in the expression of HSP70 mRNA and reach the highest at $124 \mathrm{~h}$ and expression level of HSP70 returned to about control levels following a 96-h recovery period (Cheng et al. 2007). Different from the result of Cheng et al. (2007), the relative expression level of HSP70 in this study decreased rapidly in $12 \mathrm{~h}$ after $V$. alginolyticus infection. This result may be due to quick expression of the HSP70 and the peak of the espression was less than $12 \mathrm{~h}$. Wang et al. (2011) noted that in response to the LPS challenge, the transcription of disk abalone HSP90 gene significantly increased within 2 hpi and approached maximum induction at $4 \mathrm{hpi}$. Due to the earliest analysis of of HSP in this study was at $12 \mathrm{hpi}$, the expression of the HSP at this time was already decreased.

In this study, the superoxide dismutase (SOD) activity of $H$. squamata in response to $V$. alginolyticus infection was increased at $12 \mathrm{hpi}$ and then decreases at $24 \mathrm{hpi}$ followed with normal expression started on 48 hpi (Figure 2A). Di et al. (2016) found activity SOD of $H$. diversicolor with the withering syndrome is significantly lower than in the healthy abalone. Catalase activities of infected abalone was started from 12 hpi then it was likely to decrease and there was no significant different among treatment after 72 hpi (Figure 2B). Buss et al. (2017) found that catalase CAT activity of greenlip abalone $(H$. laevigata) is significantly higher when reared at $25^{\circ} \mathrm{C}$. Different from the expression of SOD and CAT which showed a significant increase within $12 \mathrm{hpi}$, the expression of phenol oxidase was increased after 24 hpi (Figure 2C). The increasing phenol oxidase (PO) activity in $H$. diversicolor is stimulated by a viral infection (Yao et al. 2019).

Several cases of mass mortality of abalone have been recorded from several countries. Mortality of Japanese abalone Sulculus (Haliotis) diversicolor supratexta in Kanawaga, Japan in June to October 1997 is caused by Vibrio carchariae (V. harveyi) (Nishimori et al. 1998). At the nearly same time, mass mortality of the abalone Haliotis tuberculata L. has occurred in the natural environment along the south coast of Brittany, French in 1997 also caused by $V$. carchariae ( $V$. harveyi) (Nicolas et al. 2002). Mass mortality among cultured small abalone $H$. diversicolor supertexta with abscess/ulcers in the mantle in 1998 at Kao-Hsiung Taiwan was caused by V. alginolyticus (Liu et al. 2001). In China, V. alginolyticus and $V$. parahaemolyticus were associated with a severe epidemic in farmed $H$. diversicolor supertexta in Fujian Province (Zhang et al. 2001), and a Vibrio harveyi-related species was linked with the mass mortality of farmed adult H. diversicolor in Fujian (Jiang et al. 2013). Those data supported that Vibrio spp caused diseases on abalones. In this study, we reported that $V$. alginolyticus caused disease on tropical abalone (H. squamata) (Figure 4). This is the first report on confirmation of the pathogenicity of $\mathrm{V}$. alginolyticus on $H$. squamata. 
Vibrio spp. has been reported as virulent bacteria to abalone. Liu et al. (2000) reported that $\mathrm{LD}_{50}$ of $V$. parahaemolyticus on abalone $H$. diversicolor supertexta weighing $10-14 \mathrm{~g}$ is $1.6 \times 10^{5} \mathrm{cfu}$, and mortalities occurred within 2 days of infection. Cai et al. (2006a) reported that V. alginolyticus Strain 19 was virulent to abalone postlarvae with an $\mathrm{LD}_{50}$ value of $1.00 \times 10^{4} \mathrm{cfu}$. Liu et al. (2001) reported that $\mathrm{LD}_{50}$ of $V$. alginolyticus strain $\mathrm{H}-11$ on abalone $H$. diversicolor supertexta is $3.6 \times 10^{5} \mathrm{cfu}$. In this study, we also confirmed that V. alginolyticus was virulent with $\mathrm{LD}_{50}$ on $H$. squamata with an average weight of $5.13 \mathrm{~g}$ is less than $10^{5} \mathrm{cfu}$ (Figure 4).

Vibrio spp. produced and released toxins from the cells as an extra cellular product (ECP). The $\mathrm{LD}_{50}$ of ECP of $V$. alginolyticus strain $\mathrm{H}-11$ on small $H$. diversicolor supertexta is $2.96 \mu \mathrm{g}$ protein/g body weight (Liu et al. 2001), while Vibrio strain B4 has $\mathrm{LD}_{50}$ of CPS as $7.58 \mu \mathrm{g}$ protein $\mathrm{g}^{-1}$ body-weight. This toxin caused several changes in abalone organs and tissues and led to mortality. In this study, the infection of $V$. alginolyticus caused histological changes as enlargement of hemolymph sinus, development of abscess intraephitelial and intramuscular, and the intrusion of hemolymph closed to epithelial layer (Figure 5).

\section{Conclusions}

In this study, we showed that infection $V$. alginolyticus will be responsed by $H$. squamata with the rapid increasing level of HSP70 and HSP90 expression, then it was followed by decreasing level of HSP70 and HSP90 expression. Similar responses were occurred on anti-oxidant activity of SOD and CAT enzymes with delay time. Those conditions caused histological change in the tissues and led to mortality.

\section{Acknowledgments}

This study was supported by grant from the National Agency of Management Education and Fund (LPDP) of the Republic of Indonesia based on No. KEP14/LPDP/2016. We appreciated to Ni Putu Sumaryati for her assistance in V. alginolyticus preparation for this study.

\section{Authors' contributions}

NSY, M, AI, NSN designed the study. NSY conducted animal handlings and physiological studies. LA carried out the molecular laboratory work. NSY, GT analyzed the data. NSY, M, AI, NSN wrote the manuscript. All authors read and approved the final version of the manuscript.

\section{Competing interests}

The authors declare no competing interest.

\section{References}

Bondad-Reantaso MG, Subasinghe RP, Arthur JR, Ogawa K, Chinabut S, Adlard R, Tan Z, Shariff M. 2005. Disease and health management in Asian aquaculture. Vet Parasitol. 132(3-4):249-272. doi:10.1016/j.vetpar.2005.07.005.

Buss JJ, Harris JO, Currie KL, Stone DAJ. 2017. Survival and Feeding of Greenlip Abalone (Haliotis laevigata) in Response to a Commercially Available Dietary Additive at High Water Temperature. J Shellfish Res. 36(3):763-770. doi:10.2983/035.036.0326.

Cai J, Han H, Song Z, Li C, Zhou J. 2006a. Isolation and characterization of pathogenic Vibrio alginolyticus from diseased postlarval abalone, Haliotis diversicolor supertexta (Lischke). Aquacult Res. 37(12):1222-1226. doi:10.1111/j.13652109.2006.01552.x.

Cai J, Han Y, Wang Z. 2006b. Isolation of Vibrio parahaemolyticus from abalone (Haliotis diversicolor supertexta L.) postlarvae associated with mass mortalities. Aquaculture. 257(1-4):161-166. doi:10.1016/j.aquaculture.2006.03.007.

Cheng P, Liu X, Zhang G, He J. 2007. Cloning and expression analysis of a HSP70 gene from Pacific abalone (Haliotis discus hannai). Fish Shellfish Immunol. 22(1-2):77-87. doi:10.1016/j.fsi.2006.03.014.

Cheng W, Li CH, Chen JC. 2004. Effect of dissolved oxygen on the immune response of Haliotis diversicolor supertexta and its susceptibility to Vibrio parahaemolyticus. Aquaculture 232(1-4):103-115. doi:10.1016/S0044-8486(03)00488-5.

Datkhile KD, Mukhopadhyaya R, Dongre TK, Nath BB. 2009. Increased level of superoxide dismutase (SOD) activity in larvae of Chironomus ramosus (Diptera: Chironomidae) subjected to ionizing radiation. Comp Biochem Physiol, Part C: Toxicol Pharmacol. 149(4):500-506. doi:10.1016/j.cbpc.2008.11.003.

Di G, Kong X, Zhu G, Liu S, Zhang C, Ke C. 2016. Pathology and physiology of Haliotis diversicolor with withering syndrome. Aquaculture. 453(1):1-9. doi:10.1016/j.aquaculture.2015.11.030.

Fang Z, Sun Y, Zhang X, Wang G, Li Y, Wang Y, Zhang Z. 2019. Responses of HSP70 Gene to Vibrio parahaemolyticus Infection and Thermal Stress and Its Transcriptional Regulation Analysis in Haliotis diversicolor. Molecules. 24(162):1-23. doi:10.3390/molecules24010162.

Farcy E, Serpentini A, Fiévet B, Lebel JM. 2007. Identification of cDNAs encoding HSP70 and HSP90 in the abalone Haliotis tuberculata: Transcriptional induction in response to thermal stress in hemocyte primary culture. Comp Biochem Physiol, Part B: Biochem Mol Biol. 146(4):540-550. doi:10.1016/j.cbpb.2006.12.006.

Hooper C, Day R, Slocombe R, Benkendorff K, Handlinger J, Goulias J. 2014. Effects of severe heat stress on immune function, biochemistry and histopathol- 
ogy in farmed Australian abalone (hybrid Haliotis laevigata $\times$ Haliotis rubra). Aquaculture. 432(1):2637. doi:10.1016/j.aquaculture.2014.03.032.

Hsu TH, Gwo JC. 2017. Genetic diversity and stock identification of small abalone (Haliotis diversicolor) in Taiwan and Japan. PLoS ONE. 12(6):e0179818. doi:10.1371/journal.pone.0179818.

Jiang Q, Shi L, Ke C, You W, Zhao J. 2013. Identification and characterization of Vibrio harveyi associated with diseased abalone Haliotis diversicolor. Dis Aquat Org. 103(2):133-139. doi:10.3354/dao02572.

Karunasagar I, Karunasagar I, Otta SK. 2003. Disease problems affecting fish in tropical environments. J Appl Aquac. 13(3-4):231-249. doi:10.1300/J028v13n03_03.

Liu PC, Chen YC, Huang CY, Lee KK. 2000. Virulence of Vibrio parahaemolyticus isolated from cultured small abalone, Haliotis diversicolor supertexta, with withering syndrome. Lett Appl Microbiol. 31(6):433-437. doi:10.1046/j.1365-2672.2000.00843.x.

Liu PC, Chen YC, Lee KK. 2001. Pathogenicity of Vibrio alginolyticus isolated from diseased small abalone Haliotis diversicolor supertexta. Microbios. 104(408):71-77.

Magnadóttir B. 2006. Innate immunity of fish (overview). Fish Shellfish Immunol. 20(2):137-151. doi:10.1016/j.fsi.2004.09.006.

Nicolas JL, Basuyaux O, Mazurié J, Thébault A. 2002. Vibrio carchariae, a pathogen of the abalone Haliotis tuberculata. Dis Aquat Org. 50(1):35-43. doi:10.3354/dao050035.

Nishimori E, Hasegawa O, Numata T, Wakabayashi H. 1998. Vibrio carchariae causes mass mortalities in Japanese abalone, Sulculus diversicolor supratexta. Fish Pathol. 33(5):495-502. doi:10.3147/jsfp.33.495.

Park K, Lee JS, Kang JC, Kim JW, Kwak IS. 2015. Cascading effects from survival to physiological activities, and gene expression of heat shock protein 90 on the abalone Haliotis discus hannai responding to continuous thermal stress. Fish Shellfish Immunol. 42(2):233-240. doi:10.1016/j.fsi.2014.10.036.

Paulino MG, Benze TP, Sadauskas-Henrique H, Sakuragui MM, Fernandes JB, Fernandes MN. 2014. The impact of organochlorines and metals on wild fish living in a tropical hydroelectric reservoir: Bioaccumulation and histopathological biomarkers. Sci Total Environ. 497-498(1):293-306. doi:10.1016/j.scitotenv.2014.07.122.

Pridgeon JW, Klesius PH. 2012. Major bacterial diseases in aquaculture and their vaccine development. CAB Rev. 7:48. doi:10.1079/PAVSNNR20127048.

Qian Z, Liu X, Wang L, Wang X, Li Y, Xiang J, Wang P. 2012. Gene expression profiles of four heat shock proteins in response to different acute stresses in shrimp, Litopenaeus vannamei. Comp Biochem Physiol, Part C: Toxicol Pharmacol. 156(3-4):211220. doi:10.1016/j.cbpc.2012.06.001.

Roberts RJ, Agius C, Saliba C, Bossier P, Sung YY.
2010. Heat shock proteins (chaperones) in fish and shellfish and their potential role in relation to fish health: A review. J Fish Dis. 33(10):789-801. doi:10.1111/j.1365-2761.2010.01183.x.

Rungrassamee W, Leelatanawit R, Jiravanichpaisal P, Klinbunga S, Karoonuthaisiri N. 2010. Expression and distribution of three heat shock protein genes under heat shock stress and under exposure to Vibrio harveyi in Penaeus monodon. Dev Comp Immunol. 34(10):1082-1089. doi:10.1016/j.dci.2010.05.012.

Wang N, Whang I, Lee JS, Lee J. 2011. Molecular characterization and expression analysis of a heat shock protein 90 gene from disk abalone (Haliotis discus). Mol Biol Rep. 38(5):3055-3060. doi:10.1007/s11033010-9972-x.

Wang W, Vinocur B, Shoseyov O, Altman A. 2004. Role of plant heat-shock proteins and molecular chaperones in the abiotic stress response. Trends Plant Sci. 9(5):244-252. doi:10.1016/j.tplants.2004.03.006.

Xie Y, Song L, Weng Z, Liu S, Liu Z. 2015. Hsp90, Hsp60 and sHsp families of heat shock protein genes in channel catfish and their expression after bacterial infections. Fish Shellfish Immunol. 44(2):642-651. doi:10.1016/j.fsi.2015.03.027.

Yao T, Zhao MM, He J, Han T, Peng W, Zhang H, Wang JY, Jiang JZ. 2019. Gene expression and phenoloxidase activities of hemocyanin isoforms in response to pathogen infections in abalone Haliotis diversicolor. Int J Biol Macromol. 129:538-551. doi:10.1016/j.ijbiomac.2019.02.013.

Zhang Z, Wang J, Zhang J, Su Y, Huang Y, Yan Q. 2001. Bacterial diseases of Haliotis diversicolor supertexta in Dongshan, Fujian. J Oceanogr Taiwan Strait. 20(2):193-199. 